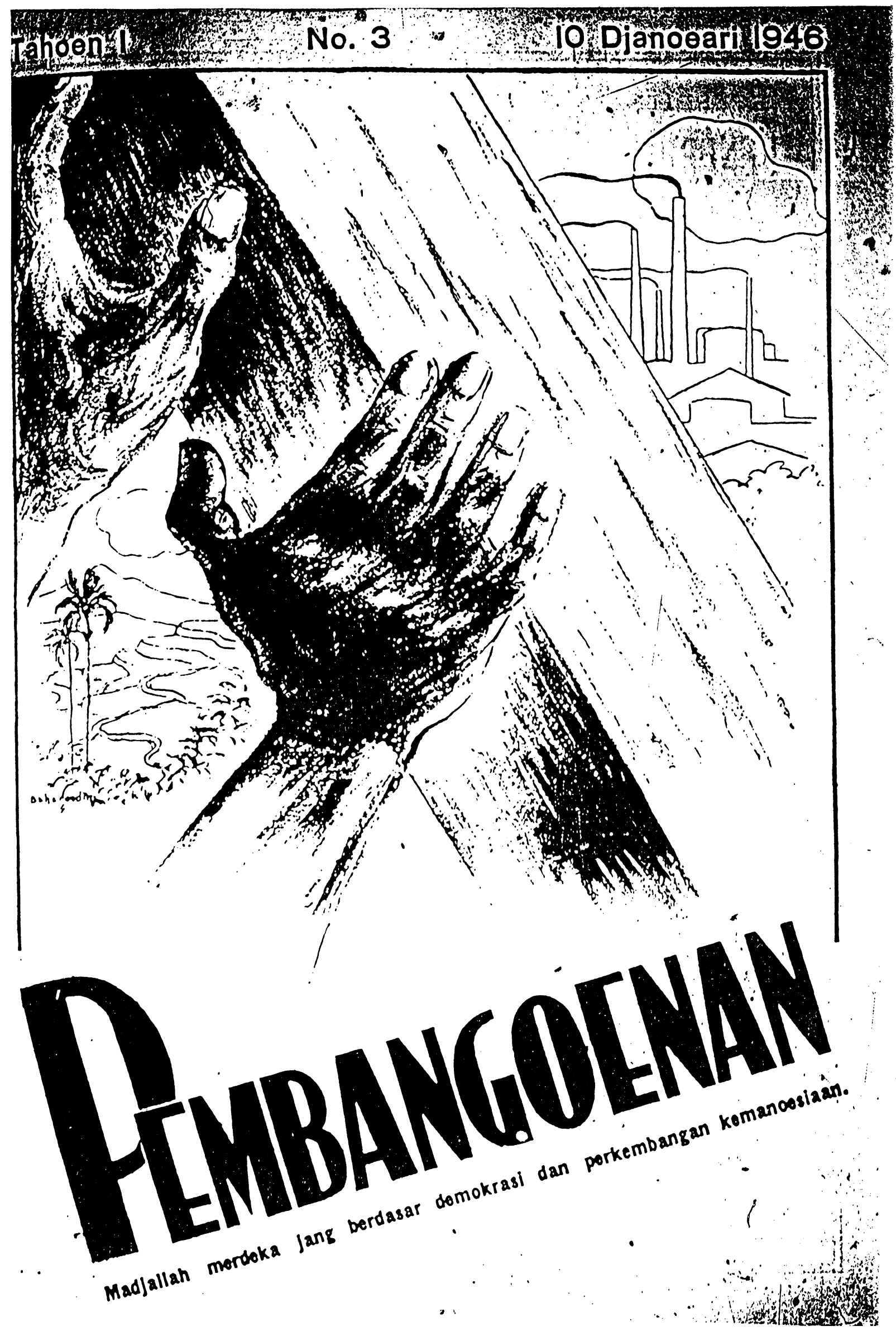




\title{
THE DEVELOPMENT OF "DEVELOPMENT"1
}

\author{
Ariel Heryanto ${ }^{2}$ \\ Translated by Nancy Lutz ${ }^{3}$
}

Approaching the end of the twentieth century, the majority of us who have had some schooling are accustomed to see the sun rise over the eastern horizon every morning. And we believe our perceptions, even though the sun has never risen over any horizon whatsoever. Our perceptions are deceived by the rotation of the earth, so that it is as though the sun rises every morning. It is not that we were never aware of this fact. Still, we are not always able to experience, control, or synthesize all the bits of knowledge we possess, including the knowledge which was passed down by Galileo Galilei over three centuries ago.

The life-giving force [daya hidup] and the deceptive force [daya tipu] of the earth's rotation are as enormous as the life-giving force and the deceptive force of the words in the language we "inhabit" every day. The difference is that, unlike words, the earth's rotation is not the product of human labor. In the last few decades, the nation of Indonesia has not only felt awakened [dibangunkan] by the rising of the sun, but also by what is CALLED [di-KATA-kan] an awakening-"Pembangunan" ["Development"]. ${ }^{4}$ Like the sun, "Pembangunan" appears to be inevitable.

The word "Development" belongs to a cross-nation-state language. 5 Together with its equivalents in various languages from other nations and traditions, "Development" can be considered one of the greatest works of mankind in this era. Like the earth's rotation which is important for life on earth, this word offers a life-giving force [daya hidup] and a work-giving force [daya kerja] to millions of human beings in this century. And like the rotation of the earth which we cannot observe clearly as long as we are on the earth, the word "Development" has an extraordinary power to deceive [daya tipu] and is rarely grasped by the consciousness of the millions of human beings in this century who live with it. Due to this miraculous word which was coined by their fellow man, human beings in various corners of the earth feel that they are seeing something real: Develop-

\footnotetext{
${ }^{1}$ The title of the original Indonesian essay is "Pembangunan" dan Pembangunan. The author himself has suggested "The Development of 'Development"' as an appropriate English translation.-TRaNs.

${ }^{2}$ This essay is a revision of an earlier draft which has benefitted from criticisms and suggestions given on separate occasions by Alton L. Becker, Donald K. Emmerson, and Herbert Feith. I would like to express my thanks to the three of them.

${ }^{3}$ I would like to thank the author and Amrih Widodo for comments on the first draft of this translation. Nevertheless, I would also like to note that neither the author nor Amrih are in any way responsible for any errors or inadequacies in this final version.-TRANS.

${ }^{4}$ This is one of the most difficult parts of the original text to translate, since a play of words is involved in Indonesian: "di-KATA-kan" is both "called" and also "worded" or "languaged" and "Pembangunan" is both the act of "awakening" and "Development."-AUTHOR.

5Ivan Illich (Gender [New York: Pantheon Books, 1982], pp. 6, 8) calls this an "industrialized language" which, according to him, "translates easily from English into Japanese or Malay."
} 
ment. ${ }^{6}$ They believe what they "see," and with various methods, styles, attitudes, and purposes, they immerse themselves in Development.

\section{Language and Development [Pembangunan]}

It is incalculable how many speeches, textbooks, seminars, kinds of propaganda, meetings, or high-level diplomatic sessions there have been in this era with the theme of "Development." Perhaps no fewer than the number of song verses, drama dialogues, advertising slogans, or examples of sentences that have been written by language teachers on the blackboard, proclaiming: "the sun rises in the east" as a "universal truth." It can no longer be calculated, how many and how far-reaching are the agreements and the political and economic decisions which have emerged from the various discussions of "Development." Nor has it been calculated how great are the funds-official or unofficial-which have not only been collected, distributed, and spent under the rubric of "Development," but which also have been used to construct, maintain, and defend the "Development" rubric itself.

Mountains, forests, valleys, rivers, oceans, air, cities, and villages are massively destroyed in the name of "Development." Human labor is exploited and self-exploited for "Development." The form and contents of conviction, honor, beauty, taste, and lifestyle, along with the system of human relations, have been massively altered by a series of gigantic and purposeful programs which are called "Development." Because of this, even though it resembles the phenomenon of the "rising" sun, in many ways "Development" cannot be called a mere illusion. The terms "reality" and "illusion" are themselves confusing elements in our language. These two terms constitute an illusion that is real, and also a reality in the form of an illusion. ${ }^{7}$

Certainly Development does not encompass everything on earth at this time, but it has become one of the greatest foci of attention for the inhabitants of this planet. Development Programs are almost always linked to a number of the problems which are considered most pressing for the majority of human beings: for example, population growth and density, hunger and poverty, employment, natural resources, industry, government organizations, technology, and the military. These problems are not the result of a mere "illusion"; they are not a reality which exists only in our imaginations. Nor does their universal existence derive solely from what is in the minds of only a few people.

On the contrary, the above problems are actually more often discussed as "real" problems which are "material," "objective," and which exist outside of, or stand apart from, human understanding, not as a fusion between things which are in our minds and language, and our environment. So that some problems escape from a general understanding of the problems of "Development." The existence of these problems is not free from some existing system of identification, observation, interpretation, and signification.

\footnotetext{
6Where the text refers only to the Indonesian word "Pembangunan" or to Development in the specifically Indonesian context, I have left it as "Pembangunan." Where the more global concept of "Development" is intended, I have translated the Indonesian word into the English "Development." Where the English word "Development" was used in the original text, I have indicated it with [sic].-TRANS.

${ }^{7}$ Compare with the statement of Clifford Gecrtz (The Interpretation of Cultures [New York: Basic Books, 1973], p. 15) concerning the understanding of "fictions, in the sense that they are 'something made,' 'something fashioned'... not that they are false, unfactual. ..."
} 
from Kompas, Wednesday, January 18, 1984, p. 4.

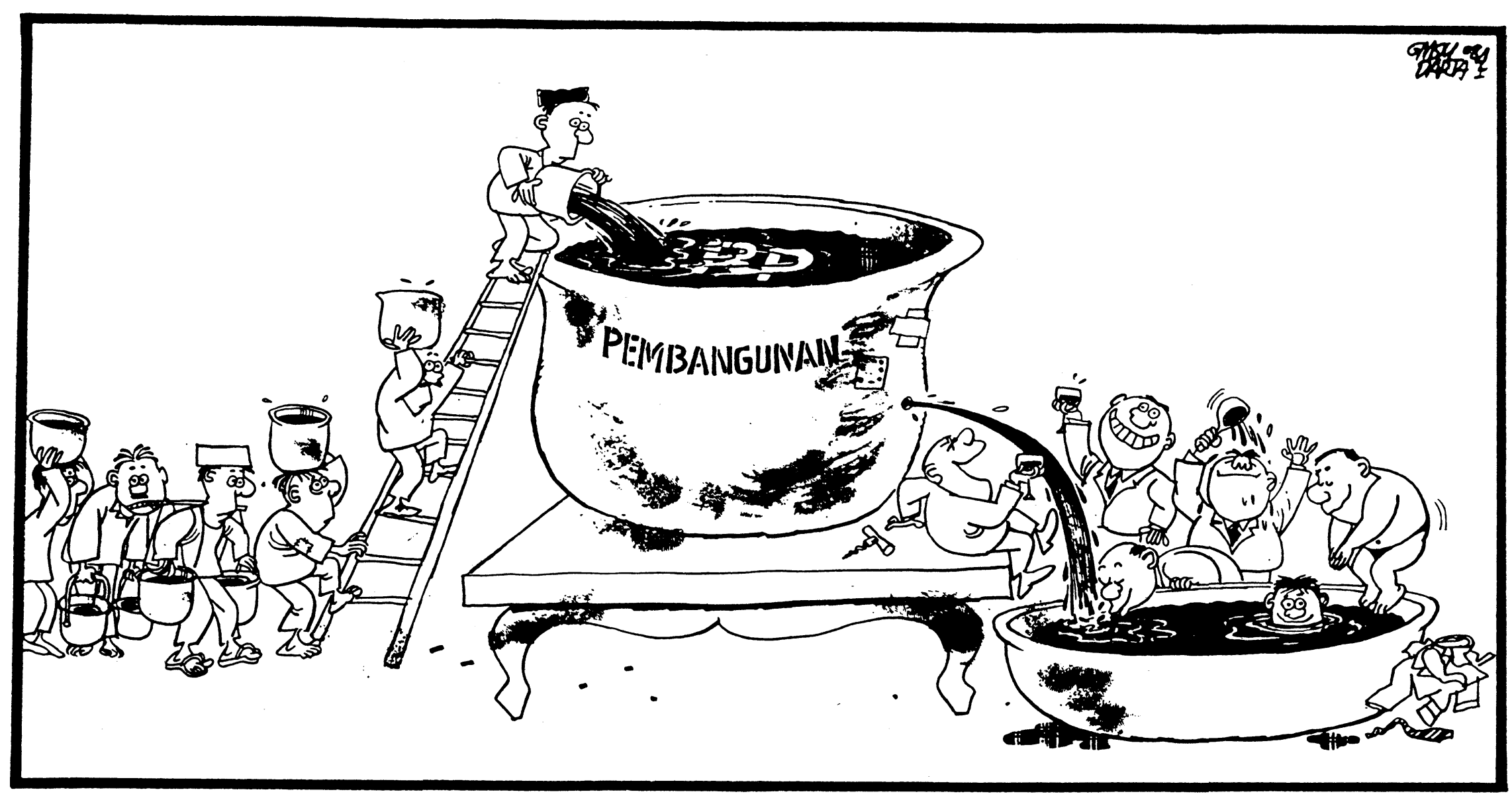


The interpretive system mentioned above can be called "culture," as suggested by Raymond Williams, and "language" can be understood as one of the most important parts of this system. 8 Without this system, none of the "realities" mentioned above would be "problems" or "questions" at all. Just as the rotation of the earth is not a "question" or "problem" for the sun, or vice versa. In our contemporary language, these problems are said to have "material" characteristics, and appear together as problems of "Development." If the word "Development" had never existed, or if we had abolished the word, none of the above material problems would vanish by themselves. But this does not in itself suggest that a key-word like "Development" is something trivial. Without this word, the above material problems would be organized in our mind and worked on by our practical labor with a different form and different contents. The disappearance of the word "Development" would topple an important part of the reality of Development which currently is shaped by this word and which cannot be replaced by any other word. The fact that words are not trivial, either in the smallest part or in the entirety of our lives, is explained by Ernst Cassirer as follows: ${ }^{9}$

No longer can man confront reality immediately; he cannot see it, as it were, face to face...He has so enveloped himself in linguistic forms, in artistic images, in mythical symbols or religious rites...here man does not live in a world of hard facts, or according to his immediate needs and desires.

In the above quotation, Cassirer emphasizes one aspect of the inability of human beings to understand reality "as it is." We must also remember that human beings have an extraordinary ability which is not possessed by any other creature. They are able to construct a system of understanding, interpretation, and explanation in order to continue and carry out their lives. This system of culture/knowledge/language did not fall from the sky and was not created as a natural event. This system was shaped by and at the same time shapes human beings and their social environment within the changes and continuities of history.

Up to the present, it has not been entirely clear to what extent students of Development Studies or Language Studies appreciate the social force of language in general, and of the word "development" ["pembangunan"] in particular. As far as I know, the fields which are known as Development Studies and Language Studies have not directed sufficient attention to these problems. It is not that there has never been serious concern with this. But efforts undertaken are still very limited, both in terms of their numbers and in terms of the strength of their influence. In most discussions of Development [Pembangunan] so far, the way in which "fictive" aspects are addressed has not been clearly defined; the same is true for the overarching system which shapes and limits both the discussion and the practice of Development; and for the key-word "development" ["pembangunan"] itself.

There is a difference between Indonesian and non-Indonesian observers in this regard. Outside Indonesia, for various reasons which it would be interesting to explore further, a number of English-language scholars have attentively observed the caprices of

\footnotetext{
${ }^{8}$ See Raymond Williams, The Sociology of Culture (London: Schoken Books, 1981), p. 13. Of course, the opinion of Williams, or of whomever, concerning the "existence" of such a "system"-and the what/how of this system-is not an "objective" description of a "reality or existence." But only in a language with "defects" like this can we explore and at the same time create the world of "reality."

${ }^{9}$ Ernst Cassirer, "A Clue to the Nature of Man: The Symbol," in Ideas of Culture: Sources and Uses, ed. Frederick C. Gamst and Edward Norbeck (New York: Holt Reinhart, 1976), p. 20.
} 
the key-word "Development" in the language fads of various areas of the world. Denis Goulet, for example, has discussed "Development" as "Liberation" since the beginning of the 1970s, and translations of his work have been published in Indonesia. ${ }^{10}$ Ivan Illich is one of the principal critics who have attacked the image and usage of the term "Development."11 He has examined the history of Western "hegemony" and the terms which emerged prominently as part of the machinery of Western power over other nations. H. W. Arndt has methodically noted the semantic history of the term "economic development" in English, especially within the Commonwealth states. ${ }^{12}$ And of course, Raymond Williams, who is known, among other reasons, for his book, Keywords, must be mentioned as a member of the small group of people who like to discuss "words" in the discourse of "Development."13 Based on Williams' ideas, Michael van Langenberg has noted several terms which he considers to be key words in the political life of the New Order. ${ }^{14}$ Nevertheless, as they each admit in their writings, the number of people like them is still small, and the contribution made by their thinking has not yet received proper attention in "Development/Pembangunan" forums.

In Indonesia, the definition of "Pembangunan" has not gone undiscussed. The most recent book by Taliziduhu Ndraha, for example, sets aside a tediously lengthy space for the various meanings of "Pembangunan," including those which he takes from "Development" [sic]. ${ }^{15}$ Nevertheless, no Indonesian thinker has specifically delved into the problem of this definition as part of the wider problem of "language" in social life, and from there tried to deconstruct the unity of the double facade-which is an "illusion" but "real"-in Pembangunan.

This does not in itself entail a criticism of Indonesian intellectuals. There are reasons to evaluate this situation as a deficiency, but there are also reasons to reject such an evaluation. Discussing this situation also implies discussing a number of essential parts of the problem of Pembangunan itself. On the one hand, it is not possible for Indonesian scholars to occupy a realm of scientific life that is separate from their colleagues in other nations. Intellectuals across nation-states are already united in and by the domination of a ("factual" and "fictional") scientific order which makes a comparative perspective possible, and which is valid as a series of scientific "laws," "logics," "pursuits," and "values" with cross-nation-state characteristics. On the other hand, the dynamics of this crossnation-state language and science originate from the "West" and in many cases are still dominated by a "Western" factual/fictional order. As a consequence, scholars from the previously colonized Eastern nations must compete from a more difficult position than that of their colleagues in the West, because the situation in their own countries does not prepare them equally well for such competition. ${ }^{16}$ Development itself constitutes

10Dennis Goulet, "Pembangunan atau pembebasan," Prisma 2, 3 (1973): 73-81.

${ }^{11}$ Ivan Illich, "Outwitting the 'Developed' Countries," New York Review of Books, November 6, 1969; idem, "The New Frontier for Arrogance: Colonization of the Informal Sector," Paper presented to the General Assembly of the Society for International Development, Colombo, Sri Langka, August 15, 1979.

${ }^{12}$ H. W. Arndt, "Economic Development: A Semantic History," Economic Development and Cultural Change 29, 5 (1981): 457-66.

13 Keywords (Oxford: Oxford University Press, 1983), pp. 102-4.

${ }_{14}$ Michael van Langenberg, "Analysing Indonesia's New Order State: A Keywords Approach," Review of Indonesian and Malayan Studies (RIMA) 20, 2 (1987): 1-47.

${ }_{15}$ Taliziduhu Ndraha, Pembangunan masyarakat: mempersiapkan masyarakat tinggal landas (Jakarta: Bina Aksara, 1987).

${ }^{16}$ As far as I know, Alton L. Becker ("Language Construction and Noetic Change: Observations on the Indonesian National Center for Language Development," Paper presented to the meeting of the Pusat Pembinaan dan Pengembangan Bahasa, Jakarta, 1983), and Benedict Anderson ("Language, Fantasy, Revolution: 
part of this competitive activity, even though to some Development seems to preserve the unbalanced nature of the competition between West and East / North and South / Rich and Poor.

In Indonesia, Development Studies cannot be said to lack a discourse of "culture," even though the majority of those involved are generally of the opinion that Pembangunan in Indonesia is too oriented towards the (growth of the) economy. Arief Budiman, for example, as one prominent figure in Indonesian Development Studies, has voiced his complaints since 1976. In his opinion, Indonesian intellectuals, tricked by theories of modernization, have too heavily stressed spiritual and cultural factors in discussing Pembangunan, while the economic experts think too technically. ${ }^{17}$ For more than a decade, Arief Budiman has continued his criticisms, both of the model of Pembangunan which is currently operating in Indonesia and of the study of Pembangunan by his colleagues, while promoting a "structural" Marxist approach. By now his ideas have become an important part of the history of Indonesian intellectual thought. Nevertheless, while his criticisms are very apt, and while his alternative proposals are dazzling, the problems of "fact-fiction," "illusion-reality," and "material-immaterial" have not yet been solved. 18 It appears that, in his position of attacking "cultural" approaches and promoting "structural" materialism, Arief Budiman has less opportunity to develop an approach which is more dialectical. Pembangunan has been repeatedly studied-and sometimes, it seems, very "radically"-but without insight into the dialectics of "Pembangunan" and Pembangunan. What is more debated, apparently, is which force is more "real" in Pembangunan: the economic system or cultural values. As though the categories "culture" and "economics" were something concrete or were the only ones which are objective.

The attention experts on Indonesian culture give to the links between culture [kebudayaan] and Pembangunan generally rests on a meaning of "culture" which is not very different from that of their critics who are more oriented towards the study of economics. The problem of the deceptive force [daya tipu] and the work-giving force [daya kerja] of words in the process of Pembangunan receives almost none of their attention. The links of language [bahasa] and Pembangunan receive sufficient attention from linguists, but get almost no attention from social scientists who specialize in Development Studies. In fact, this is not very startling in view of the difference in interests between these two groups. On the one hand, history has witnessed how the term "Pembangunan" today is usually understood in relation to "modernization," "economic

Java, 1900-1945," Paper prepared for the Annual Conference of the Association for Asian Studies, Boston, 1987), are the two experts on Indonesia who have correctly and sympathetically explored this problem. In many cases, their ideas have assisted my study of related topics.

17 See Arief Budiman, "Modernization, Development and Dependence: A Critique on the Present Model of Indonesian Development," in What Is Modern Indonesian Culture? ed. Gloria Davis (Ohio: Ohio University, 1979), pp. 201-24, especially pp. 212-14.

18For years, these problems have been "classic" in Marxist circles, and do not need to be discussed at length here (see for example, Raymond Williams, Marxism and Literature (Oxford: Oxford University Press, 1977], pp. 75-82; and Melvin Rader, Marx's Interpretation of History (New York: Oxford University Press, 1979]). Arief is not ignorant of these; he has touched on them in passing in his writings (for example, "Bentuk negara dan pemerataan hasil-hasil pembangunan," Prisma 11, 7 [1982]: 3-14 at n. 19). But what I regard as an unfortunate flaw in the brilliant works of Arief Budiman can still be encountered and moreover rather conspicuously, in his recent writings in Prisma (see, for example, "Kebudayaan kekuasaan atau sosiologi kekuasaan?" Prisma 16, 3 [1987]: 61-72). Among non-Indonesian scholars who specialize on Indonesia, the work of Richard Robison ("Culture, Politics, and Economy in the Political History of the New Order," Indonesia 31 [April 1981]: 1-29) discusses similar problems, but without providing a satisfactory solution. 
growth," and "industrialization." On the other hand, history has also witnessed the domination of an interpretation of "language" ["bahasa"] as primarily an "instrument" of communication, used to express thoughts and feelings. This is why language is considered something which is "secondary" in Pembangunan. It is also the reason why the linguists in Indonesia who zealously discuss links between language [bahasa] and Pembangunan (since in general they also share this narrow understanding of language) limit their attention to the contributions of language to the process of Pembangunan. Essentially, the students of both Development Studies and Language Studies see bahasa and Pembangunan as two things with separate realities, even though they are thought to be connectable for practical purposes at any time.

Thus, in relation to Pembangunan, language problems are primarily discussed by scholars outside the field of linguists, especially in connection with problems like illiteracy or the role of the schools and the mass media. Whereas in linguistic circles, the problems of standardization, the formation of new words, or the "control" of what they call the "propriety" of using language "well and correctly" [secara "baik dan benar"]-in support of Pembangunan-are the primary preoccupations. ${ }^{19}$ Accompanying this, the problems of "culture" ["kebudayaan"] in relation to Pembangunan are usually expressed with a feeling of apprehension: the "culture" of Indonesia is held responsible because it is thought not to support Pembangunan fully or it is bewailed because it is considered a victim of the "impact of Pembangunan."

In another paper, ${ }^{20}$ I tried to consider the major trends in the study of language in Indonesia which I have touched on above. In that paper also, I mentioned that the view of the Indonesian intelligentsia who treat language as just an "instrument" is not a continuation of the indigenous world view of traditional society. Such a view apparently was borrowed from the West, but without also borrowing the critical stance of the West, or the radical critiques of Western intellectuals.

In my opinion, the "defeat" of former colonies like Indonesia in their confrontation with outside forces cannot be separated from the "defeat" or "confusion" of their language and the world shaped by that language. The collapse of the old tradition of discourse has not yet been replaced by a new tradition sufficiently effective to respond to recent challenges. What is called [di-bahasa-kan]21 "Pembangunan" is illustrative of the phenomenon that emerges from the above trends.

Pembangunan is not a reality which exists beyond language, and language is not just an "instrument" to discuss and give names to realities outside of itself. The history of Pembangunan is not unconnected with the history of language, nor is it free from the history of the term "Pembangunan" itself. The following is only a preliminary exploration of the history of the key-word "Pembangunan" as social history.22

\footnotetext{
${ }^{19}$ The work of Dede Oetomo is one of the few encouraging examples of an exploration by an Indonesian of the problem of language in Indonesia. (See Dede Oetomo, "Bahasa dan perubahan sosial di kota-kota Indonesia: aspek kebahasaan stratifikasi sosial," Kritis 1, 3 [1987]: 54-64.) Language here is understood as more complex and dynamic than just an "instrument" of communication.

20 "Kekuasaan, kebahasaan, dan perubahan sosial," Kritis 1, 3 (1987): 1-53.

21 See above, n. 4.-TRANS.

22 At the time of completing this paper, I am undertaking a more macro study of the relationship of the histories of language and Development in Indonesia in my research on "Language and Development: The Case of Indonesia," sponsored by the fellowship problem on "Reflections on Development" (1987-1988) of the Rockefeller Foundation.
} 


\section{The Biography of "Pembangunan"}

Every word has a social history, but not all words are equally important in social life. The word "Pembangunan" in present-day Indonesian not only has become what Raymond Williams would call a key-word, but it has also become one of the two most important key-words (the other is Pancasila). As key-words, these terms are "significant," "binding," and "indicative ... in certain forms of thought." 23

It is not really clear precisely when, by whom, in what context, and why the word "Pembangunan" was first used in Indonesia. But there are sufficient reasons to convince us-for the time being - that this word is relatively new. Perhaps since the beginning of its history, the meaning of this word has been changing. But what is clear is that all the shifts and variations in its meaning have occurred in the "modern" era and basically refer to a social reality which is "modern." It is this fact which clearly differentiates the history of the term "Pembangunan" from the history of the other derivatives of the rootword "bangun."

While "bangun" and a number of other words which are formed from this root-word are very old (who knows how old), the word "pembangunan" cannot be found in the ancient manuscripts of the early societies of the archipelago, including those whose languages later became the ancestors of present-day Indonesian. Because of this, "pembangunan" is only used to refer to contemporary societies, not earlier than the beginning of this century and more specifically and prominently the second half of this century. In other words, it refers to the period that followed the end of the Second World War and the rise of Independence in many nations which were or had once been colonized. The term "Pembangunan" was not used, at least until the present period, to discuss social transformations in the era of the ancient kingdoms of Sriwijaya, Kediri, Majapahit, or even Mataram. Nor do the experts in Development Studies usually include the era of the ancient kingdoms when unraveling the history of Pembangunan in Indonesia. Moreover, there are those in this era of the New Order who consider the history of Pembangunan in Indonesia to have begun only "since the birth of the New Order," 24 or else in 1969 with the onset of the first REPELITA [Five-Year Development Plan] under the New Order government. ${ }^{25}$ Whereas in fact, "Pembangunan," with a sense that was not significantly different, had already been part of Soekarno's thinking and government programs. ${ }^{26}$

Our generation can still discern how recent "pembangunan" is. The earliest dictionary I have found which includes the term is no more than 40 years old, 27 even though Malay dictionaries which are older include various words with the root "bangun." Our generation thus can inspect the recent historical borders of this key-word. What is called "Pembangunan" is one product of a particular history, and in a particular manner participates in the formation of social history. Thus, we should not make the

\footnotetext{
23 Williams, Keyzords, p. 23.

${ }^{24}$ Harpalis Alwi, "Merenungkan Hari Kebangkitan Nasional: rasa percaya diri sebagai modal pembangunan," Sinar Harapan, May 10, 1985, p. 6.

${ }^{25}$ Abdul Gafur et al., "Pokok-pokok pikiran mengenai rantap tentang pertanggungjawaban Presiden/Mendataris MPR-RI dikaitkan dengan Bapak Pembangunan Indonesia" (Jakarta: n.p., October 3, 1982), p. 4.

26Ndraha, Pembangunan masyarakat, p. 60.

27 See A. L. N. Kramer, Sr., ed., Kamoes Indonesia; Indonesisch-Nederlands en Nederlands-Indonesisch (Jakarta: Van Goor, 1948), p. 17.
} 
mistakes that occurred with several other key-words in our language; for example, "culture," "language," "art," or "religion." Too often we have heard discussions on the subject of traditional "culture" or "art," which are often contrasted with what is called modern "culture" or "art." As if all the modern trends and categories such as "culture" and "art" had a universal character, and were also found in traditional societies. 28

Although posşibly not its earliest occurrence, the word "pembangunan" was used frequently and publicly in the well-known Cultural Polemics [Polemik Kebudayaan] of the second half of the 1930 s. $^{29}$ Certainly this fact is not particularly surprising. The terms and concepts which sprang up at that time were often connected with the initial stirrings of Indonesian nationalism. A projection or image to be "developed" ["terbangun"] in the following éra became a critical issue amongst the intelligentsia. The meaning of "pembangunan" and "membangunkan" at that time can perhaps best be understood as equivalent to "building" in "nation-building" and "character-building," which became such popular expressions in subsequent periods.

The Indonesian intellectual who was most controversial in the Cultural Polemics, and who five decades later still remains the foremost figure of "modernism" in Indonesia, is Sutan Takdir Alisjahbana. He repeatedly used the terms "pembangunan" and "membangunkan," although he also felt it necessary to mention the foreign expressions he had in mind: "... the task of young Indonesia is cultuurscheppen, to develop a new culture. . ."30 The meaning of scheppen itself was usually translated in Indonesian as "menciptakan," or in English as "to create."31 A decade after the Cultural Polemics, Sutan Takdir Alisjahbana directed the publication of "an illustrated magazine [madjallah 'with two l's'] based on democracy and human development," entitled Pembangoenan. ${ }^{32}$ As a candidate for the title of "Father of the Idea of Development" ["Bapak Pencetus Ide Pembangunan"] (as distinguished from "Father of [the Program of] Development" ["Bapak (Program) Pembangunan"]) in Indonesia, Sutan Takdir Alisjahbana might therefore be nominated.

Basically, the various verbs with the root-word "bangun" can be grouped into two major clusters of meaning, although a breakdown of each cluster would include finer variations. ${ }^{33}$ The first cluster includes meanings which are related to the activity of constructing buildings / houses / bridges / roads, etc. In the second cluster, we find meanings which are related to the activity of changing something or to a person changing from a state of sleeping / lying down / unconsciousness to becoming awakened / up-

\footnotetext{
${ }^{28}$ As is the case with "pembangunan," the fundamental meanings of these terms derive from modern Europe, although in Indonesia they are presented with "indigenous" roots.

${ }^{29}$ See several of the essays from these Polemics which have been edited and published in Achdiat Karta Mihardja, ed., Polemik kebudayaan, 3rd ed. (Jakarta: Dunia Pustaka Jaya, 1977).

30 Ibid., p. 17.

${ }^{31}$ See Soekartini, ed., Kamus Bahasa Belanda-Indonesia (Bandung: Sumur, 1972), p. 588, and Fernand G. Renier, ed., Dutch Dictionary (London: Routledge \& Kegan Paul, 1949), p. 251.

${ }^{32}$ This magazine was published in Jakarta by Penerbit Kebangsaan Poestaka Rakjat, twice a month, on the 10th and the 25th, beginning on December 10, 1945.

${ }^{33}$ See the formal and common meanings given by various dictionaries: Rev. W. G. Shellabear, ed., $A$ MalayEnglish Vocabulary (Singapore: American Mission Press, 1902); L. Th. Mayer, Practisch Maleisch-Hollandsch en Hollandsch-Maleisch Handwoordenboek, 3rd ed. (Amsterdam: Scheltema \& Holkema, 1906); R. J. Wilkinson, ed., An Abridged Malay-English Dictionary (Kuala Lumpur: The F.M.S. Government Press, 1908); Kramer, Kamoes Indonesia; A. L. N. Kramer, Sr., Concise Indonesian Dictionary (The Hague: Van Goor, 1952); Ph.S. Van Ronkel, ed., Maleisch Woordenboek, 3rd ed. (The Hague: Van Goor, 1930); and W. J. S. Poerwadarminta, ed., Kamus Umum Bahasa Indonesia (Jakarta: Balai Pustaka, 1952).
} 
right / conscious. However, in the newer noun form, "pembangunan," as used by Sutan Takdir Alisjahbana in the Cultural Polemics and in the magazine Pembangoenan, we come across several basic meanings which have been "modernized" [diperbaharui], broadened in some aspects and specialized in others. To my mind, in the context of the growth of nationalist thinking, the basic meanings of the word "pembangunan" revolved around the meanings of: (a) "to arouse" [membangkitkan] that which was previously asleep; or (b) "to bring about" [mengadakan] that which previously did not exist (which becomes the fundamental meaning of "to create" [mencipta]); or (c) to "modernize" [memperbaharui] / reorganize on a large scale that which had already long existed. Concretely, these meanings had distinct targets: to arouse nationalist consciousness; to bring about an independent Indonesia; and to modernize [memperbaharui] the way of life of a society which had formerly been colonized.

To some extent, these basic meanings and the metaphoric framework of "Pembangunan" which was established in the past have determined the direction and characteristics of later developments and their resulting social implications. In any case, three factors can be identified in these trends. First, in the ensuing years which brought Indonesian society into a markedly different period of history, the two major clusters of meaning, "(mem-)/(di-) bangun (-kan)," continued to hold. Second, as was the case when it was first formed, "Pembangunan" in later years continued to represent a fusion of indigenous linguistic materials on the one hand with a foreign spirit and "modern" concepts on the other. Third, against the background of this fusion, "Pembangunan" declared a passion for creation of the "new" and rejection of the "old," the two being seen as opposed to one another.

For a nationalist intellectual like Sutan Takdir Alisjahbana, the creation of the term "pembangunan" constituted something which was necessary and vital. In this endeavor, the two major clusters in the meanings of "bangun" were very useful. On the one hand, this word could translate the meaning of "building" (a society which was new and which was called a nation). On the other hand, this same word could also give additional reinforcement to the struggle of "nation-building" as an "awakening" (of popular consciousness). In the Cultural Polemics, Sutan Takdir Alisjahbana tried to take maximum advantage of the metaphor of "bangun" with its two major clusters of meanings. As though he were discussing tearing down a house, he talked about "the collapse of the old traditie" in order to build something new, so that "people's eyes would be opened." $34 \mathrm{He}$ denounced the statements of his colleagues which praised Eastern civilization, because he saw such statements as diverging from the aspirations of Pembangunan, and as "lulling many people to sleep." 35 In the first issue of the magazine, Pembangoenan, Sutan Takdir Alisjahbana wrote an editorial, "Opening Words," which ended with the sentence, "And finally..., so that the building, Independent Indonesia, which is in the process of being erected, will be mighty and beautiful and strong. ..."36 With a sense that still revolves around this idea, the lyrics of the national anthem, Indonesia Raya, "build its spirit, build its body" ["bangunlah jiwanya, bangunlah badannya"], presumably get reemphasis. Three decades after the Indonesian nation-state projected by the nationalists in the Cultural Polemics became a reality, the old metaphor was not completely extinct.

\footnotetext{
${ }_{34}^{34}$ Mihardja, Polemik kebudayaan, p. 65.

${ }^{35}$ Ibid., p. 19.

36 "Dan achirnya..., agar gedoeng Indonesia merdeka jang sedang didirikan itoe hadsjat dan permai dan koekoeh...."-TRANS.
} 
President Soeharto described the national Development program [progam nasional Pembangunan] as "just like people erecting a large building." 37

It must be noted that "Pembangunan" in the New Order led by President Soeharto is not exactly the same as the "Pembangoenan" discussed by Sutan Takdir Alisjahbana in the Cultural Polemics. The social order of Indonesia and of the world in general were and are very different in these two periods. After Indonesian Independence, the formal "building" ["bangunan"] of the Indonesian nation-state was already manifest; but "Pembangunan" did not immediately become a salient key-word. As we know, "Revolusi" ["Revolution"] was the most important key-word during the late President Sukarno's administration. Only in the New Order has "Pembangunan" reached the peak of its achievement as a key-word. President Sukarno bore the title, "Great Leader of the Revolution" ["Pemimpin Besar Revolusi"]; President Soeharto is named "Father of Development" ["Bapak Pembangunan"]. The current administration has not only called itself the "New Order" ["Orde Baru"], but also the "Development Order" ["Orde Pembangunan"]. All the cabinets in the New Order administration have been called "Development Cabinets" ["Kabinet Pembangunan"]. Various names for institutions, social activities, and abstract concepts have been given the appendage, "Pembangunan." This key-word has become a focus of authority and legitimacy, and a departure point from which to re-interpret old facts and direct the future course of history.

The differences between the "Pembangunan" of the Cultural Polemics and that of the New Order can be further investigated in order to add to our understanding of the second topic mentioned above (the fusion of indigenous and foreign languages). New Order "Pembangunan" is no longer a creative experiment in the expression of foreign ideas, as it was in the era of the Cultural Polemics. Rather, it is a distinct response to foreign ideas which utilizes the historical legacy furnished by the Cultural Polemics. "Pembangunan" is no longer equivalent to the particulars of (nation-) building, but rather to Development [sic]. In any event, this means that, even with the change in its meaning, the appearance and skyrocketing social status of the word "Pembangunan" have not been free from the interference of key-concepts from outside Indonesia. This does not in itself, however, mean that "Pembangunan" is exactly identical to Development [sic], as was perhaps suggested by Illich's opinion quoted at the beginning of this essay. Such a thing could never happen. Each word has its own social space, historical status, and ancestors, all of which are different, though interconnected. Within Indonesian, we have witnessed the uniqueness of the double metaphors of the word "bangun," which has no single equivalent in the English language. 38 And beyond the internal linguistic issues, "Development" [sic] certainly is not identical to "Pembangunan." Ivan Illich was not mistaken when he testified to the decline in the reputation of the ideals and slogans of "Development" [sic] in many parts of the world, although perhaps not to the extent suggested by his explosive words. ${ }^{39}$ His opinion was shared by Herbert Feith in "The Decline of Developmentalism as an Ideology," which he modestly described as "avowedly speculative... in bald and unqualified form to provoke controversy." 40 Nevertheless, three years after such testimonies were presented (and were heard by the

37 Soeharto, Kumpulan kata-kata Presiden Soeharto 1967-1971 (Jakarta: Sekretariat Kabinet RI, 1971 ), p. 45.

38 Of course, this does not mean that words with the root-word "bangun" are more "powerful" [hebat] than those which usually correspond to them, such as "to build" or "to develop." Each of these words has a space and a history of its own which is different and unique.

39 Illich, "New Frontier for Arrogance," p. 7.

40 Herbert Feith, "Legitimacy Questions and the Suharto Polity," Paper prepared for the Australian National University's Seminar Series on "The Indonesian Connection," November 23, 1979. 
Indonesian intelligentsia), the Indonesian government proclaimed the title "Orde Pembangunan" ["Development Order"] for the "Orde Baru" ["New Order"], and "Bapak Pembangunan" ["Father of Development"] for the President who was in power.

Finally, on the third topic (the conflict of "old" and "new"), Alisjahbana's rhetoric in the Cultural Polemics is especially interesting to us: "only those who can free themselves from the old will be able to ... build [membangun] the new." 41 And pembangunan of the new "... means the collapse of the old traditie." 42 In the present era, a similar conflict was expressed by the naming of the "New Order" ["Orde Baru"] as opposed to the "Old Order" ["Orde Lama"]. Furthermore, the conflict of "old" / "tradition" versus "new" / "modern," which was one of the dominant themes of the Cultural Polemics, still colors discussions among the Indonesian intelligentsia, as shown by the fact that they held a 50 th anniversary of the Cultural Polemics in Jakarta in 1986. A critique of views which split and separate things that in fact are historically inseparable was nicely presented by Y.B. Mangunwijaya and Ignas Kleden. ${ }^{43}$ Previously, such views, with their fatally ahistorical character, had been continually and fundamentally questioned by Arief Budiman. 44 This matter is better understood historically; for example, from the process involved in the formation of the word "pembangunan" itself.

The use of the term "pembangunan" in the Cultural Polemics appears less extraordinary if we remember that various words with the root "bangun" were already widely used in the previous periods. However, if we consider why it was only in the decades of the rise of nationalism that verbs using the root "bangun" became nominalized, we are tempted to consider a wider range of possibilities. Not only was the formation of the noun "pembangunan" a "creative" act of discourse, but the act of "membangun" also gained a new interpretation deriving from Western culture; namely, "creation": to bring about [mengadakan] something which previously did not exist. Just as God's "creation" of the universe in various religions, or "creation" in the history of Western art since the Romantic period (which greatly influenced Sutan Takdir Alisjahbana and his associates) were not seen as processes of social history, so the "creation" of Pembangunan was seen as fundamentally urged by a drive to create [mengadakan] something from nothingness. The "creative" quality of mankind was idealized as God, coinciding with the secularization of the life of educated people at that time. Also since then, this creative creature has frequently been discussed in the abstract as "Man" with a capital "M."

The framework of ideas which existed at that time also made it possible to imagine another outcome of the labor of "building" ["membangun"] which had not previously existed, and which in fact had been unimaginable: the nation. ${ }^{45}$ In order to explain such imaginings to the public of the time, "creative" people like Sutan Takdir Alisjahbana felt it necessary to oppose every inclination to understand the nation-to-be as a continuation of the growth of "traditional," "old" societies. Sutan Takdir Alisjahbana's commitment was also expressed in his striving not to use the old words formed by the root-word

\footnotetext{
41 Mihardja, Polemik kebudayaan, p. 65.

42 lbid.

${ }^{43}$ See Y. B. Mangunwijaya, "Menghantar generasi pasca," 2 pts., Kompas, August 18, 19, 1986; and Ignas Keleden, "Membangun tradisi tanpa sikap tradisional," Prisma 15, 8 (1986): 69_86.

${ }^{44}$ See, for example, Arief Budiman, "Ilmu-ilmu sosial Indonesia a-historis," Interview in Prisma 12, 6 (1983): 74-89.

${ }^{45}$ Benedict Anderson's idea of the nation as an "imagined community" is very interesting. See Benedict Anderson, Imagined Communities (London: Verso, 1983). If the existence of the nation is in the imagination, then the history of its formation must also be studied in the history of the imagination.
} 
"bangun," but instead to abstract the act of "membangun" into the noun "pembangunan." Thus the formation of the historic noun "pembangunan" (from a verb which had long been available) constituted a revolutionary event. This abstract noun, once it had become general and was followed by abstractions of various other words, changed the focus of attention and the world view of the society concerned. If in the old society of Nusantara "membangun" had a concrete and clearly limited meaning signifying a certain activity, the people who would carry it out, what was to be done, the manner of working, and its place, time, and purpose, then now people were invited to imagine, think about, or discuss "Pembangunan" as an abstraction. It was also this abstraction which enabled the formation of a cross-nation-state consciousness. Linked to "Development," "Pembangunan" referred to the general idea of an activity which (it was hoped) would occur in many parts of the world.

\section{Dialectics}

The above analysis shows how complex and dynamic the biography of "Pembangunan" is. Nevertheless, these dynamics and this complexity have not yet been analyzed in a detailed way. Therefore I would now like to consider several aspects which I consider important. Fundamentally, the dynamics of the meaning of "Pembangunan" can be understood as a dialectic: in the scope of relations between key-words, in the relations between nation-states, and in the relations between the material and non-material forms of "Pembangunan."

\section{The Imbalance Between Nation-States}

Social scientists have often discussed the imbalance between the wealthy industrial states on the one hand and the "formerly" colonized states on the other. It is not necessary, nor is this writer competent, to review their analyses here. Nonetheless, there are several things which need to be repeated because of their relevance to the subject of this paper. The imbalance in relations between the two above groups of states is most often revealed in political-economic relations, and sometimes also in the military domain. My earlier arguments suggest a further correlation, although to a more limited degree, in the field of language. Weaker states are required to use the language-meaning that they must follow the logic and the methods of understanding which are part of this language-that belongs to the states which are stronger in their inter-relations; stronger, that is, not only in diplomacy, and in the distribution of financial or military "aid" or of political legitimacy, which are marks of cooperative relations, but also stronger in competition and in conflict.

Imbalances of this sort do not only occur in the relations between strong and weak states, but also in the relations among hierarchically arranged social groups, including the peoples or ethnic groups which are under the authority of each of the above-mentioned states. In the interactions between states, including those which are related to Development programs, usually only a fraction of the citizens of each nation-state are

directly involved. Because of this, the development [sic] which spread and later flowered in the "developing" states [negara "berkembang"] as "Development" has more controlled than been controlled by the majority of the members of society. This fact seems very obvious in many of the nations which fall in the "weaker" category. 
In the past several years, students of Development Studies have been impressed and preoccupied with the emergence of a number of Newly Industrializing Countries within the Asian region. Usually these countries are studied as cases demonstrating the "success" of states which have engaged in "Development." Not infrequently, moreover, these states are considered to have become competitors which threaten the "West." Thus criticisms of "Development" ["Pembangunan"], and of "dependency" on Western power centers are strongly challenged. Nevertheless, we need to study further what is meant by the "success" of "Development" programs in these several Asian states. Fundamentally, we must ask whether the success of "Development" is the same as "good," and what is meant here by "good." Basically, it requires a further study of the definition of "Development" itself. To define "Development" as Illich suggested means defining basic human needs and their fulfillment. ${ }^{46}$ While the several Asian states which appear "successful" in "Development" certainly deserve our respect and admiration, we can still observe the strength of the "Western" definition in defining basic human needs and the fulfillment of those needs across nation-states, quite apart from the problem of the content of that definition. 47 The hegemony of a particular definition reaches its peak whenever it occurs together with a more fundamental and supporting hegemony in the form of a cross-nation-state standardization of views on language, including a standardization of the meaning of "definition."

In connection with this, we can also observe an asymmetry between the participation of intellectuals from the so-called "developing" nations and that of their colleagues from "developed" nations in the activity called "Development Studies." When an Indonesian who has been to school endeavors to study the problem of "Pembangunan" in Indonesia itself, he has a hard time avoiding the structure of "Development Studies," which grew up and is still centered outside Indonesia yet has a cross-nation-state scope. Once he realizes this, he is then more inclined to study the "grammar" which is current in "Development Studies" circles than to study what Indonesian society is all about. Yet what else can he do? There is not yet an alternative "grammar" (even supposing there is a desire for one) of Development Studies à la Indonesia or à la Java/Bali/Sunda/Malaya, etc. which is stable, systematic, and institutionalized. What we have instead are just a number of Indonesianized, Javanized, or similarly ethnicized, "biases" or "dialects," which are perhaps unintentional, resulting from our effort to talk about Development

46.llich, "Outwitting the 'Developed' Countries," and "New Frontiers for Arrogance."

${ }^{47}$ The testimony of the two intellectuals below adequately represents the dominant public opinion, I think, whether or not we approve of this dominance. Cautiously, Christer Gunnarsson notes: “Of course concepts such as development and underdevelopment are highly normative.... In a general sense, however, ... development means an improvement in the standard of living, which is achieved by an increase in the production and consumption of goods and services. Industrialization is neither the only possible means of achieving progress, nor need it be the best. However, when we speak of the developed countries of today we refer to the industrialized countries, which means that the industrial society is the archtype of the modern developed society." (Christer Gunnarsson, "Development Theory and Third World Industrialization," Journal of Contemporary Asia 15, 2 [1985]: 184.) Although with a more cynical attitude, Ivan Illich's formulation is not far different: "Fundamentally, development implies the replacement of general competence and abundant subsistence activities by the use and consumption of commodities.... It implies the redefinition of needs in terms of goods and services mass produced according to expert design." (Illich, "New Frontier for Arrogance," p. 7.) 
with a "grammar" that comes from the West. ${ }^{48}$ Westernization, although it clearly exists and is unavoidable, has never been total.

\section{Perkembangan, Pembangunan, Development}

The dialectic summarized above in the relative political-economic strengths of nation-states also has important implications for the use of words, although these implications may not be direct or completely parallel. In keeping with the limitations of my ability and the space available here, I will only discuss two other words, namely, "perkembangan" and "development."

As we know, and as I touched on earlier, "Pembangunan" today has become the equivalent of the English word "Development." This is different from "Pembangoenan" in the era of the Cultural Polemics, which had as its equivalent, "(nation)-building." Moreover, before the noun "pembangunan" was formed, the word "development" was already familiar to Indonesian intellectuals and had been translated into Malay. The English-Malay dictionary compiled by Shellabear translated "development" as "kkmbangan, ktumbohan, kmajuan," but NOT as "pmbangunan." 49 The change in the Indonesian equivalent of "development" took place not only because the Indonesian words like "perkembangan" and "pembangunan" changed their meanings, but because "development" itself experienced a fairly extensive shift in meaning from its sense at the time Shellabear compiled his dictionary.

The contrast between "perkembangan" and "pembangunan" is very striking and conveys an important message here. Morphologically, "perkembangan" is linked to the word "berkembang," which in contemporary educated speech is considered an intransitive verb. "Berkembang" is based on the root-word "kembang," which is a synonym of bunga, "flower." Initially, "berkembang" indicated the process of growth of a seed into a plant, which buds and then FLOWERS, completing the growth or maturation of the plant. An understanding of this process can also be used by the proprietors of the language as a metaphor for various apparently similar matters or events. The most popular references are to the "growth" 50 of the body, spirit, or mind of human beings (from children and childhood to adults), or to the development of some incident (from the emergence of a crisis or conflict, to the surmounting of the crisis, to a resolution of the crisis). Fundamentally, the meaning of "perkembangan" refers to a PROCESS of change which is continuous, which has the qualities of being NATURAL, and which takes place because of a thrust of energy from WITHIN the organic matter involved, even if it also uses contributions of energy from outside.

The extension of the words "berkembang" and "perkembangan" to human beings and events expresses the view of the proprietors of the language involved towards the nature of human beings and events. The growth and maturation of human beings /

\footnotetext{
${ }^{48}$ I suppose similar things happen to studies in almost all the various fields which come from the intelligentsia. The most recent prominent examples are the problems of "gender/feminism" and "nuclear/peace," while "democracy," "basic rights," "culture," and "science/technology" remain prominent.

${ }^{49}$ Rev. W. G. Shellabear, ed., An English-Malay Dictionary (Singapore: The Methodist Publishing House, 1916), pp. $143-44$.

50 The term "flora" ["tumbuh-tumbuhan"] is another name for creatures which have "flowers" ["kembang"]. The limited correspondence between the translation "growth" and "pertumbuhan" is no less than that between "development" and "perkembangan."
} 
society and the development [perkembangan] of social affairs are viewed as "natural," not fully subjugated to the wishes or plans of any person, but managed by the laws of nature. Asking about the "development" ["perkembangan"] of an incident of conflict presupposes a desire, concern, and hope regarding matters which cannot yet be determined because they are outside our control. Believing that an incident "develops" ["berkembang"] -in a society that once believed in the existence of a supernatural force regulating the order of the universe-combines a hope that the incident will be controlled by the laws of nature with a hope for its resolution through the return of the original order and harmony. A flower which develops from a seed will bear fruit and become a seed again. Although having several special characteristics, the process of flowering is no more than a progression of sprouting, growing, 51 bearing fruit, and forming seeds. There is thus a "religious" quality to the meaning of "berkembang."

The word "Pembangunan" not only has a meaning which is different from "perkembangan," but furthermore derives from a world view that is radically different. Up to the present, people who speak Indonesian are not accustomed to discussing the "pembangunan" of children into adults, or the "pembangunan" of an incident from a crisis to a settlement or resolution. Although "bangun" has two large clusters of meanings, as has been explained above, the word "pembangunan" constitutes a nominal form of the transitive verb "membangun" in the sense of "erecting a building" ["mendirikan bangunan"] (such as a house, a building, etc.). The further away we are from the era of the Cultural Polemics, the clearer it is that the term "Pembangunan" stresses only one of the meaning clusters of the root-word "bangun." The nominal form of "bangun" ["wake"] (from sleep) is "kebangunan," which is often used interchangeably with the term "kebangkitan" ["rise"], but not with "pembangunan."

Fundamentally, "pembangunan" does not refer to a natural process, but to a process of ENGINEERING, with primary orientation to the man-made or artificial PRODUCT which it yields, which has the characteristics of being NEW; or to the process of CREATING something which was formerly non-existent by mobilizing forces from OUTSIDE the object concerned. As in the original use of the term "pembangunan" in the context of erecting structures/houses/buildings, the current use of this metaphor refers to the reliance on a conscious human will, on a work plan, on funds, and on technology, science, and the exploitation of natural and human resources, in the interests of the same or other human beings. This is also the reason, again different from "perkembangan," that "pembangunan" demands legitimation, justification, and a number of debatable ethical considerations.

Up until now, both "perkembangan" and "pembangunan" have usually been translated in English as "development." The contrast between "perkembangan" and "pembangunan" is not clearly marked in such an English translation, although this does not mean that the contrast cannot be accommodated within the English word. "Development" can be used with a sense that is close either to "perkembangan" or to "pembangunan." The choice for the past several decades of "pembangunan" and not "perkembangan" as an Indonesian key word for "development," therefore, appears rather strange if we consider that (i) for years "development" had been translated as "perkembangan," and not as "pembangunan"; and (ii) when "pembangunan" was formed as the nominal form of "membangun," the term "(nation)-building," and not "development," was its equivalent. What initially appears strange, however, appears

${ }^{51}$ Contrast the word belonging to societies which think linearly, "grown-up." 
logical if we recognize the semantic change of "development." The recent history of "development," therefore, must also be considered in order to understand the dominance of "pembangunan" as its equivalent in Indonesian. As I mentioned above, the history of the term "development" has been instructively analyzed by Ivan Illich, H. W. Arndt, and Raymond Williams. For the purposes of our discussion here, I will briefly summarize below several points in Arndt's analysis.

Arndt shows how recent and how significant the semantic change of "development" was in English. Formerly this term covered a very broad and general concept, before it became focused on notions of "economic development," "progress," "economic growth," "modernization," and "industrialization" in one specific group of societies in what is now called the Third World. According to Arndt, this shift began to occur in the last century, although it only developed on a large scale in the last part of this century. This is the reason, says Arndt, that the Oxford English Dictionary still has not included the specialized or technical interpretations of "development" as an important part of the language of Economics. 52 Nor has the Encyclopedia of the Social Sciences yet included a specific entry entitled "economic development." It might also be noted, moreover, that Raymond Williams' book, Keywords, did not include "development" in its first (1976) edition. Only in the second, revised edition was the derivation of this key term included.

The other part of Arndt's study which is interesting and very important is the existence of two major groups in the development of the meanings of "(economic) development" in modern English. The first has its source in colonial authority; the second in Marxist thinking. In the first group, "development" constitutes the nominalization of a transitive verb, while in the second, "development" constitutes the nominalization of an intransitive verb.

In the first group (the "colonial"), the key term "development" is used primarily in the sense of natural energy resources, and later also human resources, which are $D I$ bangun/kembang-KAN ("being developed"). The agent which $M E$-mbangun/ngembang$K A N$ [does the developing] is usually understood to be the government: "[i]t was always seen to need government initiative, action to 'develop' the ... resources. ..."53 In the second group (the "Marxist"), the key term "development" is understood-not by all, but by a considerable number of Marxists-primarily in the sense of a process of historical change which takes place without having to be intentionally or even fully consciously desired by anyone: society can BER-kembang [develop] or bangun [arise] by itself.

This shift, which Arndt notes, in the central meaning of "development" in English to a technical or specific sense in Economics, has been considered one decisive source for the biography of the contemporary Indonesian term "pembangunan." More specifically, it has been observed that it is the (ex-)colonial sense of "development" which became the prevailing meaning of "pembangunan" in Indonesia.

Arndt has helped us to understand that there is more than one fundamental sense of "development." With reference to the contrast between "perkembangan" and "pembangunan," we can say that both groups of meanings are contained in the one English word. Whether or not it is accurate to identify these two senses of "development" as "Marxist" or "colonial" legacies, is debatable. What is clear, however, is that these two senses of "development," like the contrast between "perkembangan"

\footnotetext{
52 Arndt, "Economic Development," p. 457.

53 Ibid., p. 462.
} 
and "pembangunan," can be compared from the point of view of the Western grammatical distinction between "transitive" and "intransitive" verbs. Thus we can say that the choice of "pembangunan," and not "perkembangan," in response to the extensive pressures exerted on various nation-states by the contemporary term "development" is at least partially influenced by the dominance of the transitive meaning of "development."

Of course this phenomenon cannot be reduced to merely a formal grammatical explanation. Grammar is not a natural law or even a force which autonomously regulates the concrete relations among human beings. Rather, this phenomenon suggests the growth [bertumbuhnya] of a way of viewing the history of society as something which no longer develops [berkembang] "naturally" because of energy from WITHIN its own dynamics, but which "should and must" BE developed [dibangun]!

The above analysis of the triangle "perkembangan" / "pembangunan" / "development" does not, of course, completely explain all the various facets of these three words. The analysis here only explains a number of points which I consider important regarding the recent intimacy of "development" with "pembangunan" after many years of being close to "perkembangan," and after the widening of the meaning of "development." However, exceptions to the general phenomena explained above are not absent or unusual. Neither is the above analysis an indication that the dynamics of Indonesian words only reflect the dynamics of English key-words.

The phrase "developing nation/country," for instance, is an example which is not in accord with the above analysis. The word "developing" in "developing country" is what in English grammar is called a "present participle," not a "gerund." The word "developing" is derived from the intransitive verb "to develop," and thus differs from the transitive orientation of the word "Development" which currently dominates the discussions of states or national programs. This is also the reason why the phrase " "developing nation/country" is translated in Indonesian as "bangsa/negara berkembang." Again, an analysis which limits itself to the context of formal grammar is not at all satisfying unless accompanied by an understanding of the ideological aspects involved. Why, for example, does the current dominance of the transitive nature of "Development" thinking impinge on another key-word with an intransitive character? This question brings us to an illustration of the point I mentioned above, namely, the relative autonomy of Indonesian language and society in Pembangunan-ing in the midst of parties who are preoccupied with Develop-ing.

The intransitive variant of the term "developing nation/country," which occurs in gaps in the dominant transitive orientation of "Development" thinking, has implications which are different for "Development speaking communities" than for societies which are "Pembangunan speaking."The intransitive variant seems to be more important for the former group of societies than for the latter. It also conceals the complexities of which party which should be more responsible for the implementation of Development/Pembangunan and its results. This interpretation, therefore, is distinguishable from more general commentaries which say that the term "developing nation/country" is only a "euphemism," or a refinement of previous terms used by English-speaking societies, such as "backward," "undeveloped," or "underdeveloped."

Ideologically, the term "developing nation/country" conceals the existence of an agent in the process of Development in a society, especially one who comes from OUTSIDE. As though a country "develops" according to its own desires and limitations rather 
than "is developed." If the picture given is of a "country which is developed," then the question of responsibility comes to the fore, and such questions arise as: Who is doing the "developing"? What is the basis of their legitimacy? Who is being benefitted and who has to pay the costs?

These questions are more sensitive for those coming from outside than for those within the "developing nation/country" concerned. Although Indonesia, for example, follows the rhetoric of a "developing nation/country" with its use of the term "bangsal negara berkembang," the leaders of the Indonesian nation-state [bangsa/negara] itself do not seem to worry about the problem of responsibility. This fact was strikingly shown by the glorification of the title "Father of Development" ["Bapak Pembangunan"] for President Soeharto at precisely the moment when "Development" became a target of criticism in various parts of the world. To a lesser extent, the same problem was shown by the choice of the term "Pembangunan," which gives more prominence to the transitive nature of this activity than does the term "Development." The transitive nature of the term "Development" is less apparent, not only because this word includes both the transitive and intransitive meanings of "to develop," but also because the transitive nature of "Development" is expressed as an abstraction of the actual activity, and not as the activity itself. If the problem of responsibility in the meaning of "membangun" constitutes a significant problem to be avoided or concealed in Indonesia, then the leaders of Indonesian society should translate "Development" as "Kebangunan" rather than "Pembangunan."

Ideologically, the term "developing nation/country" has a number of other implications, which also differ for the agents of Development who come from outside and for those within the society. The term "negara berkembang" ["developing country"] is a fairly effective slogan in Indonesia, indicating a kind of "progress" ["kemajuan"] or "development" ["perkembangan"] which has a positive value in the society concerned. In reply to the various criticisms and complaints about the negative aspects of Pembangunan, the term "negara berkembang" is repeatedly used as a kind of protective shield: "You know, this is a nation-state which is still in the process of developing" ["maklumlah, ini kan bangsa/negara yang masih sedang berkembang"]. Moreover, even when it is evident that a "developing nation" is ALREADY very active in development, 54 it continues to be called a nation which is STILL developing [berkembangkembang].

In a more global context, the term "developing nation" is often paired with a term which is rather difficult to translate into Indonesian, "developed nation." This pair of terms invites people to view and divide the various nations of the world into only two types: still in the process of "developing" or already thorougly "developed." Furthermore, this way of speaking pushes people to differentiate one nation from another on a continuum between two poles: those which have just begun, those which are already somewhat, those which are more, and those which are very "developed." The connection between these two poles creates a straight line which is considered to represent the path of linear history. Not all images of polarization are accompanied by such evaluations, where one pole is ascribed the characteristics "perfect" and "good," while the other is considered "bad" and "defective" and must be perfected or corrected by moving towards the first pole. Nations which are called "developing" are nations which are

${ }^{54}$ The Indonesian term here is berkembang-kempis ("panting"), which forms a play on words with the term berkembang-kembang ("developing and flowering").-AUTHOR. 
endeavoring to improve their lives, but the interpretation of "good" here is imprisoned by the dominant language. There is only one hope for a nation which is in the process of "developing," namely, to become "developed." And a definition is already available for a nation which is already "developed." 55 Because of this, "cooperation" between "developing" and "developed" nations is often called "aid" from the latter to the former. This way of speaking, which is rampant, gives the impression that nations which are ALREADY "developed" need nothing further, and thus differ from nations in the process of "developing" which still hope to become "developed" but are not able to do so themselves. Criticisms pointing out that what happens is precisely the reverse have frequently been expressed, and recently have also been refined and made more sophisticated.

Before moving on to the next topic, I would like to present a couple of additional notes on the curious term, "Father of Development" ["Bapak Pembangunan"]. As I mentioned earlier, this title is rather unique. Its lexical formation was made possible, among other things, by the self-confidence of the leaders of Indonesian society about the prestige of Pembangunan in Indonesia, and by the clearly "transitive" character of the terms "pembangunan" and "membangun." Nevertheless, why was the term "Father" ["Bapak"] chosen for this title?

Sukarno bore the title "Leader" ["Pemimpin"], because he was the highest person in a society whose key-word was "Revolution." In the struggle of a "Revolution," a "Leader" is more important than a "Father." So why didn't President Soeharto adopt the title "(Great) Leader of Development" ["Pemimpin (Besar) Pembangunan"]? Or, for that matter, any of the other possible titles besides "Father," if "(Great) Leader of Development" was considered too suggestive of the "Old Order," reminding us, as it does, of Soekarno as the "Great Leader of the Revolution" ["Pemimpin Besar Revolusi"]? In the Pembangunan of Indonesia, is a "Father" more important than a "Leader"? If so, why? Here again, the nature of "Pembangunan" appears to be different from that of "Development." It is hard to imagine the reaction of the institutional leaders of Development in the capitals of the "developed" countries, if they were given the title, "Father of Development."

Observers of Indonesian society, I am sure, would be inclined to link this problem with what is called "Bapak-ism." Without intending to reject or belittle such an interpretation, I would like to examine this topic by linking it to the earlier discussion of the differences between "perkembangan" and "pembangunan," and between a world view which sees the order of the world regulated by the laws of "nature" and one which sees nature as raw material which must be di-exploitasi [exploited], di-"developed" [sic], or di"bangun" ["built"]. It seems that the choice, and up to a certain point, the official acceptance, of the title, "Father of Development" ["Bapak Pembangunan"], constitutes a revitalization of the old view which emphasizes a "natural" authority and over-all order. This is very different from the "modernist" stance with its spirit of "rationality à la the West" which was proclaimed by Sutan Takdir Alisjahbana in the initial period of the promotion of "Pembangoenan."

It may be a mistake if we excessively contrast the concepts of "Leader" ["Pemimpin"] and "Father" ["Bapak"]. Perhaps what we should consider instead is the use of the concepts "Father as Leader" ["Bapak sebagai Pemimpin"] and "Leader as Father" ["Pemimpin sebagai Bapak"], which actually is not far different from a discussion of "Bapak-ism." The

55 See footnote number 33 above. 
difference is that discussions of "Bapak-ism" usually limit their attention to the relationship of "Bapak" and "anak buah" as patron and client. For our purposes, we must broaden our focus to at least the concept of "family" ["keluarga"], especially as it is related to the concept of "universe" in the mind of the society concerned. The creation of the Father-Child [Bapak-Anak] relationship is shaped by a process which is not only social, but natural. It is "natural" because a Father cannot choose the children he begets, nor can a child choose his or her natal Father. The relationship of a Father and his children is "given" by fate, destiny, God, or whatever else we wish to call the force that created the universe.

The presence of a Father of Development [Bapak Pembangunan], therefore, explains Pembangunan as a unit of social activity with "familial" characteristics. Such a Father is head of the family in the Pembangunan household not because he desires to occupy this position, but because of the will of destiny. As a Father, he is not a person chosen through an election, who is lent a mandate of authority for a limited time by his electors, and who must take responsibility for his actions as holder of this borrowed mandate. In the Indonesian family, as well as in the families of various societies outside Indonesia, there is a prohibition against children "sinning" [mendurhaka] against their Father, no matter how culpable the Father in the eyes of his children. A Father is a father to his children not only during his lifetime, but even after his death. Likewise, children have only one natal father, not only in their lifetimes but even after their deaths. In the original text proposed for the bestowal of the title "Father of Development" ["Bapak Pembangunan"] on President Soeharto, Abdul Gafur and his team wrote:

Thus the title Father of Indonesian Development [Bapak Pembangunan Indonesia] will be the property of only one person and is not to be given to any other person. This means that the Father of Indonesian Development [Bapak Pembangunan Indonesia] is one [manunggal] with our present national leader, Pak Harto. 56

The one who is called "our national leader" ["pemimpin nasional kita"] here is not called the "Leader" ["Pemimpin"] of Development, but rather "a central figure in the process of national development." 57

The above analysis is not intended as a description of President Soeharto, the honorable bearer of the title, "Father of Development," nor of his wishes. This title was given to him. Nor is the above analysis intended, at least directly, as an interpretation of the thoughts and intentions of the parties who planned or suggested bestowing this honorary title. The analysis only points out a number of the implications of the meaning given to such titles, by considering the history of Indonesian language and society. The extent to which the implications of the meanings given represent or misrepresent reality as perceived and manipulated by certain parties constitutes a separate discussion which is beyond the scope of this essay.

\section{The Practice of Pembangunan}

The history of Development in various parts of the Third World has often been discussed in a general manner, since it is considered to have a number of common features. Pembangunan in Indonesia has characteristics which are unique, as was discussed above;

56 Gafur et al., "Pokok-pokok pikiran," p. 4.

57 Ibid. 
it also has characteristics which are general, as will be summarized below. These characteristics are not far different from the semantic framework of "development" which we have already discussed at length.

First, the image of something NEW is very important and is glorified. Pembangunan, which since the beginning of its history in Indonesia, like Development in a number of other countries, has been linked to the concept of "modernization," not only works at renovating the life of society, but also opposes, rejects, and eradicates (on a small or large scale, openly or not) anything which is considered "traditional" or "antimodernization." A few things which are "traditional" are tolerated and given the right to exist, but the tolerance varies greatly, as do the tolerating parties. Those leaders of society who are most acutely afflicted with the ideology of "modernization" are also the least inclined to tolerate anything which is valued as "traditional." The tolerance seen in some of their rhetoric is limited in scope, appearing primarily as seasoning in their speeches, or as cultural window dressing, to safeguard the status quo or to avoid disruptive social tension. Things which are "traditional" are used as antique or esoteric "spectacles" in the midst of a wave of industrialization which is occurring in culture and in the commodity trade for tourists.

Second, within the Pembangunan process, there are a number of special rights and legitimacies which are given to those who plan, control, and enjoy the fruits of Pembangunan. Since there is a sense-among other senses-of Pembangunan as a work of engineering, a number of specialists / experts / technocrats are given special rights to plan and determine the direction and path of Pembangunan for the "people" in general. These parties are some of the "agents" or "actors" involved in the transitive sense of the words "membangun" and "Pembangunan." From these "special" experts, moreover, the authorities usually get confirmation and legitimation of the direction and path of Pembangunan through a series of sophisticated theories, definitions, slogans, and statistical figures.

Third, in contrast to "perkembangan," which refers to a natural process, Pembangunan realizes itself by exhausting and disrupting the natural environment as a source of raw materials. Even the government has admitted making such extravagant sacrifices. Additionally, like the "pembangunan" of a structure/building/house, Pembangunan of the nation is carried out through a large-scale recruiting (mobilizing) of the energy of members of society. In order to get "positive" legitimacy, this matter must be explained with language which is also "positive": for example, terms like "participation" ["partisipasi"], "mutual cooperation" ["gotong-royong"], or "self-supporting" ["swasembada"]. In contrast to the special "participation" of a small number of elites, this "participation" of the masses is seldom balanced by rights or by an equalization of the opportunity to control the process or to enjoy the fruits of this "mutual cooperation." Demands for equalization and for a balance of rights have occasionally been made. But there also exists an effective language to counter these demands; for example, the accusation that such demands constitute a threat to "national stability and security," or more moderately, the excuse that, "you know, this is a country which is STILL in the process of developing."

Fourth, still linked to the older sense of "membangun rumah" ["building a house"], Pembangunan nasional [national Development] has shown its most impressive achievements in the creation of a number of physical buildings. The majority of Indonesia-watchers are of the opinion that, up to the present, the Pembangunan led by the New Order has focused primarily on the creation and improvement of the infrastructure for 
industrialization. Recent national Pembangunan has not only been busy erecting buildings for various offices, factories, schools, or multi-story skyscrapers, but has also been engaged in the building of highways (which are freed from "wild" pedicabs [becak] andong] and sidewalk vendors), 58 public parks, sophisticated telecommunications networks, and military weaponry.

We often hear. complaints about the "imbalance" of material and non-material Pembangunan, to the effect that the non-material sectors of life are being neglected. In a number of instances, for example in the amount of investment and attention which has been directed towards material things like technology and industry, such complaints are not unfounded. Nevertheless, this does not mean that Pembangunan of the non-material sectors is minimal or insignificant. As has already been described in the first part of this essay, human beings always live in between veils of meaning. With or without non-material Pembangunan programs which are intentional or planned by the government, a set of systems of signification always "develops" in society as a response to the encompassing realities of material Pembangunan.

In the history of modern Indonesian society, the growth of the systems of meaning given to Pembangunan is not a completely "natural" process, let alone a "wild" process. There are efforts which are planned and controlled by the wielders of authority, although their success is not unlimited. Some of these efforts as described in the above analysis have appropriated terms and phrases like "modernization," "traditional," "participation," "mutual cooperation," "self-supporting," and "national stability and security." Moreover, this entire essay shows the importance of the Development [Pembangunan] of the meaning of the word "pembangunan" itself. Non-material Development, especially language, is not just an "impact" of material Development. Nonmaterial Development is an integral part of the implementation of Development. An observer of this matter need not be a linguist to realize the swiftness of the changes which have occurred in the Indonesian linguistic usages which originated from the elite. Like cooking which has too much MSG, ${ }^{59}$ Indonesian is thick with technocratic terms: "engineering" ["rekayasa"], "proposal" ["usulan"], "target" ["lesan"], "scope" ["teba"], "input" ["masukan"], "impact" ["dampak"], "obstacle" ["kendala"], "transfer" ["alih"], "interact" ["saling-tindak"], "standard" ["baku"], "random" ["acak"], "monitor" ["pantau"], "coverage" ["liputan"], "sophisticated" ["canggih"], "relevant" ["penad"], "valid" ["sahih"], "labor-intensive" ["padat-karya"], "rationale" ["penalaran"], or "takeoff" ["lepas-landas"]. These terms are different from terms like "Pembangunan." According to Illich, the former are "technical terms" [sic], which are different from a term like "Pembangunan" (or "Development") which is a "key word," not only in the sense defined by Raymond Williams, who in turn inspired Illich, but also in the sense that "it imputes a basic need" [sic]. ${ }^{60}$

"Pembangunan" is not only an important product of the process of Pembangunan. "Pembangunan" is a core element and source of energy for the practice of Pembangunan. Language does not function merely as a "tool" greasing the wheels of Pembangunan, as if it were lubricating oil in a gigantic machine. Rather, it is within language that Pembangunan operates, and it is in the complexities of a dynamic language that the

\footnotetext{
$58 \mathrm{~A}$ major issue in the city of Jakarta (and to a lesser extent in the other metropolitan areas of Indonesia) has been the removal of street vendors and small vehicles-especially becak and andong-from major streets and highways.-TRANS.

59 Monosodium Glutamate, an additive which is considered a "flavor enhancer."

${ }^{60}$ See Illich, Gender, p. 5 . See also Williams, Keywords.
} 
24 ARIEL HERYANTO

complexities of Pembangunan are often unrecognized. Failure to understand the dynamics of language is just as fatal to our comprehension of Pembangunan, as failure to understand the rotational movements of the earth is to our perceptions of the universe. 